\title{
A Review on Post-Harvest Profile of Sweet Potato
}

\section{Chaitali Chakraborty $^{1 *}$, Rupsa Roychowdhury ${ }^{1}$, Suravi Chakraborty ${ }^{1}$, Prostuti Chakravorty ${ }^{1}$ and Debjit Ghosh ${ }^{2}$}

\author{
${ }^{1}$ Department of Food Technology, Guru Nanak Institute of Technology, 157/F, Nilgunj Road, \\ Panihati, Sodepur, Kolkata-700114, West Bengal, India \\ ${ }^{2}$ Don-Limon GmbH, Hamburg, Germany \\ *Corresponding author
}

Keywords

Sweet potato, Curing, storage, Packaging, $\mathrm{m}$ Marketing, Spoilage.

Article Info

Accepted:

19 April 2017

Available Online:

10 May 2017
Due to rapid increase in demand for grain both as food and feed, there is an urgent need substitution of grain starch with other starch substrate like sweet potato for food security and bioenergy production.Sweet potato, a bio-efficient crop grown for edible roots has spread into Africa, Asia, Europe and East Indies through Batatas line and to the Philippines from Central and South America. Sweet potatoes may be harvested whenever they reach a marketable size. Under good growing conditions, harvesting may begin 90 to 100 days after planting of some varieties and continue until well after frost has killed the vines and leaves. Sweet potatoes should be stored between 12 and $16^{\circ} \mathrm{C}\left(54\right.$ and $\left.61^{\circ} \mathrm{F}\right)$ with a $\mathrm{RH}$ of $80-95 \%$ and proper ventilation during storage to maximize potential storage time. Respiration causes the production of $\mathrm{CO}_{2}$, which will act to increase the rate of spoilage. Thus Sweet potato possess unique physic-chemical characteristics of starch for value addition and industrial use.

\section{Introduction}

The sweet potato (Ipomoea batatas) is a native American plant found by Columbus and his shipmates, probably on the West Indies islands of the coast of Yucatan and Honduras. Despite its name, the sweet potato is not related to the potato. Sweet potatoes belong to the morning glory family, while potatoes are members of the Solanaceae family. Sweet potatoes became popular very early in the islands of the Pacific Ocean, spreading from Polynesia to Japan and the Philippines. One reason is that they were a reliable crop in cases of crop failure of other staple foods because of typhoon flooding.
They are featured in many favourite dishes in Japan, Taiwan, the Philippines, and other island nations. Indonesia, Vietnam, India, and some other Asian countries are also large sweet potato growers (Onwueme, 1978).

Early records have indicated that the sweet potato is a staple food source for many indigenous populations in Central and South Americas, Ryukyu Island, Africa, the Caribbean, the Maori people, Hawaiians, and Papua New Guineans. Protein contents of sweet potato leaves and roots range from $4.0 \%$ to $27.0 \%$ and $1.0 \%$ to $9.0 \%$, 
respectively. The sweet potato could be considered as an excellent novel source of natural health-promoting compounds, such as $\beta$-carotene and anthocyanins, for the functional food market. Also, the high concentration of anthocyanin and $\beta$-carotene in sweet potato, combined with the high stability of the color extract make it a promising and healthier alternative to synthetic coloring agents in food systems (Bovell-Benjamin, 2007).

In agriculture, post harvest handling is the stage of crop production immediately following harvest, including cooling, cleaning, sorting and packaging. The instant a crop is removed from the ground, or separated from its parent plant, it begins to deteriorate. Post harvest treatment largely determines final quality, whether a crop is sold for fresh consumption or used as an ingredient in a processed food product (Woolfe, 1992).

\section{Harvesting and Handling}

Sweet potatoes have thin, delicate skin that is easily damaged by cuts and abrasion (Mukunyadzi, 2003). Striking the roots with harvesting equipment or dropping them into containers injures their skin. Bruises and abrasions must be kept at a minimum. The sweet potato may be cut or bruised if they are placed in containers having sharp edges or roughly hauled or handled (Sumner, 1984). Impact loggers located at the centre of sacks indicated that the most severe impacts (greater than 20g) occurred during unloading and loading from road vehicles and ships. However, skinning injury and broken roots were correlated with a large number of minor impacts ( $2 \mathrm{~g}$ or lower). The use of cardboard boxes filled with fewer roots instead of overfilled polypropylene sacks and adoption of improved management procedures in the handling and transport are recommended (Tomlins et al., 2003).

\section{Curing}

Curing to promote wound healing is found as the most suitable method to control microbial spoilage. Curing naturally occurs in tropical climates where mean day temperature during sweet potato harvesting season (FebruaryApril) invariably remains at $32-35^{\circ} \mathrm{C}$ and relative humidity at $80-95 \%$. Sweet potato varieties varied in their root dry matter content and low root dry matter content attributed for their high curing efficiency. Curing efficiency of varieties also differed in response to curing periods (Ray and Ravi, 2007). Sumner, 1984, reported that, sufficient exchange of air in the curing room should be allowed to prevent the accumulation of carbon dioxide produced by the roots or depletion of oxygen consumed by them. If condensation is excessive, it is removed by ventilation. The primary purpose of curing is to heal injuries so that the sweet potatoes remain in good condition for marketing during the winter and to preserve "seed" roots for the next crop. Healing takes place rapidly at 85 degrees Fahrenheit and 85 to 90 percent relative humidity. Curing should start as soon after harvest as possible to heal injuries before disease-producing organisms gain entrance. Healing involves production of cells that are very much like the skin in their ability to prevent infection. According to Mukunyadzi, 2009, some benefits and problems associated with curing are mentioned below:

\section{Benefits of curing}

Curing enhances culinary characteristics such as combination of color, texture, aroma and fiber content. Proper curing has been shown to increase the sensation of moistness and sweetness, enhance the aroma and decrease the starch content while increasing the sugar.

Curing aids in wound healing and reduces losses due to shrinkage and disease. 
Freshly harvested sweet potatoes have thin, delicate skin that is easily broken, scraped or otherwise removed, thus curing helps to set the skin.

\section{Problems associated with improper curing}

Inadequate and excessive curing can shorten shelf life, increase sprouting during storage and result in excessive weight loss. Normal weight loss should not exceed $5-8 \%$ of the freshly harvested weight.

Improper ventilation during curing can result in an extremely low oxygen or high carbon dioxide environment.

Curing at improper temperature and humidity can reduce quality during storage. Low humidity also results in inadequate healing of wounds.

Curing that continues for too long can result in wide spread sprouting. It is not unusual to see short (less than one-fourth inch) sprout buds on a few roots toward the end of curing. However, wide spread sprouting results in rapid weight loss.

\section{Storage}

The next step for production of high quality sweet potatoes is the storage in the proper environment. The primary goal of the storage is to maintain root quality and ensure an adequate supply throughout the year by minimizing both physiological disorders and disease development. Low temperature stressinduced phenolic compounds may increase the antioxidant activity as well as the nutraceutical value of sweet potatoes [Ipomoea batatas (L.) Lam].

Cured and non-cured roots of 'Beauregard' sweet potatoes were exposed to low temperature storage $\left(5^{\circ} \mathrm{C}\right)$ for up to 4 weeks. A significant increase in total phenolic content in cured and non-cured roots was observed after 2 weeks of low temperature exposure. However, an increase in the antioxidant activity after 3 weeks of storage at $5{ }^{\circ} \mathrm{C}$ was noticed only in non-cured roots. After 4 weeks of storage at $5{ }^{\circ} \mathrm{C}$, non-cured roots accumulated higher total phenolics and antioxidant activity than cured roots. Among tissue locations, the highest phenolic content and antioxidant activity were found in the periderm tissue and the lowest in the pith tissue. A 3-day exposure period to ambient temperature $\left(\sim 22{ }^{\circ} \mathrm{C}\right)$ following low temperature storage resulted in a significant increase in antioxidant activity in periderm tissue (Padda and Picha, 2007).

Sweet potato storage roots are subjected to several forms of post harvest spoilage in the tropical climate during transportation from field to market and during storage. These are due to mechanical injury, weight loss, sprouting, and pests and diseases. Sweet potato weevil is the single most important storage pest in tropical regions for which no control measures or resistant variety are yet available. Several microorganisms (mostly fungi) have been found to induce spoilage in sweet potatoes during storage.

The most important among them are Botryodiplodia theobromae, Ceratocystis fimbriata, Fusarium spp., and Rhizopus oryzae. The other less frequently occurring spoilage microorganisms include Cochliobolus lunatus (Curvularia lunata), Macrophomina phaseolina, Sclerotium rolfsii, Rhizoctonia solani, Plenodomus destruens. Microbial spoilage of sweet potato is found associated with decrease in starch, total sugar, organic acid (ascorbic acid and oxalic acid) contents with concomitant increase in polyphenols, ethylene, and in some instances phytoalexins (Ray and Ravi, 2007). 
As reported by Mukunyadzi et al., (2009), Problems associated with improper storage conditions are as follows:

Sweet potatoes lose dry matter through natural respiration and pithiness is very common in sweet potatoes held for very long periods in poorly controlled storage facilities.

An effect of elevated storage temperature is sprouting. At temperature above $60^{\circ} \mathrm{F}$, sweet potatoes will sprout.

Storage below $50^{\circ} \mathrm{F}$ can result in chilling injury.

If humidity is low, sweet potatoes will lose weight as moisture evaporates from the surface of roots. This results in weight loss and may cause shriveling of the skin especially at the root ends.

According to Grace et al., (2013):

Purple sweet potato; NCPuR02-020, contained highest levels of all phenolic components.

A decrease in phenolic components was observed after curing and storage.

Covington contained the highest level of betacarotene and total carotenoids.

Levels of carotenoids were significantly increased over curing and storage times.

Antioxidant activity and ascorbic acid gradually decreased with storage.

\section{Packaging}

The packaging of sweet potatoes is an industrial operation that should be dedicated to delivering the highest quality product to the consumer. The current market demands uniformity in appearance in both colour and size, which necessities long and complicated packaging lines. Unfortunately long packaging lines can increase the opportunity for skinning, bruises, cuts, and broken ends that detract from appearance and increase the possibility for disease development (Steed et al., 2008).

Clark and Moyer 1988, gave some recommendation to reduce damage on packaging lines:

Dump roots slowly into water (not onto roots) in the dump tank.

Use high-quality padding on all impact surfaces.

Use long inclines to reduce drop heights between components.

Reduce the number of drops and turns.

Reduce the overall length of the packing line.

Remove belt supports (if feasible) to reduce impact.

Use deceleration flaps and blankets $\mathrm{t}$ reduce the speed over drops.

Instruct workers to handle roots with care, and monitor handling frequently.

Avoid abrupt changes in direction and speed of belts. Add padding if turns are avoidable. Reduce packing line speed.

\section{Shipping}

An estimation shows that as much as 5 percent of packed sweet potatoes are lost annually during transportation to market. Much of the loss is a direct result of mishandling during shipment. To reduce 
losses, the shippers, truckers, and receivers should be well acquainted with the specific handling requirements of sweet potato. Packaged and palletized sweet potatoes awaiting shipment should be refrigerated at $55^{\circ} \mathrm{F}$ and 85 percent relative humidity immediately after packaging (Mukunyadzi, 2009).

\section{Marketing}

According to Mukunyadzi, 2009 market life begins when roots are removed from bulk storage bins. Market life includes washing, packing, and distribution to market, and it concludes at the point of consumer purchase.

Table.1 Diseases Caused by Weevil Species

\begin{tabular}{|c|c|c|c|}
\hline Name of the Pest & Description & Damage & Control or Solution \\
\hline $\begin{array}{l}\text { Sweet potato } \\
\text { Weevils } \\
\text { (Cylas spp.) } \\
\text { (Coleoptera: } \\
\text { Curculionidae) }\end{array}$ & $\begin{array}{l}\text { Three species of the } \\
\text { genus Cylas are pests } \\
\text { of sweetpotato; they } \\
\text { are commonly called } \\
\text { sweetpotato weevils. } \\
\text { All three species- } \\
\text { Cylas formicarius, C. } \\
\text { puncticollis, and C. } \\
\text { brunneus-are found } \\
\text { in Africa. } \\
\text { formicarius is present } \\
\text { in Asia and in parts of } \\
\text { the Caribbean. } \\
\text { The elongated ant-like } \\
\text { adults of the three } \\
\text { species can be } \\
\text { distinguished from } \\
\text { each other. In all } \\
\text { species, the eggs are } \\
\text { shiny and round. The } \\
\text { legless larvae are white } \\
\text { and } \\
\text { curved, and the pupae } \\
\text { are white. }\end{array}$ & $\begin{array}{l}\text { Adult sweet potato } \\
\text { weevils feed on the } \\
\text { epidermis of vines and } \\
\text { leaves. Adults also feed } \\
\text { on the external surfaces } \\
\text { of storage roots, causing } \\
\text { round feeding punctures, } \\
\text { The developing larvae of } \\
\text { the weevil tunnel in the } \\
\text { vines and storage roots, } \\
\text { causing significant } \\
\text { damage. Frass is } \\
\text { deposited in the tunnels. } \\
\text { In response to damage, } \\
\text { storage roots produce } \\
\text { toxic terpenes, which } \\
\text { render storage roots } \\
\text { inedible even at low } \\
\text { concentrations and low } \\
\text { levels of physical } \\
\text { damage. Feeding inside } \\
\text { the vines causes } \\
\text { malformation, } \\
\text { thickening, and cracking } \\
\text { of the affected vine. }\end{array}$ & $\begin{array}{l}\text { When sweet potato weevil } \\
\text { populations are high, no } \\
\text { single control method } \\
\text { provides adequate } \\
\text { protection. The integration } \\
\text { of different techniques, } \\
\text { with emphasis on the } \\
\text { prevention of infestation, } \\
\text { provides sustainable } \\
\text { protection. Use of } \\
\text { uninfested planting } \\
\text { material, especially vine } \\
\text { tips. } \\
\text { Crop rotation. } \\
\text { Removal of volunteer } \\
\text { plants and crop debris } \\
\text { (sanitation). } \\
\text { Flooding the field for } 24 \\
\text { hours after completing a } \\
\text { harvest. } \\
\text { Timely planting and } \\
\text { prompt harvesting to avoid } \\
\text { a dry period. } \\
\text { Removal of alternate, wild } \\
\text { hosts. } \\
\text { Planting away from } \\
\text { weevil-infested fields. } \\
\text { Hilling-up of soil around } \\
\text { the base of plants and } \\
\text { filling in of soil cracks. } \\
\text { Applying sufficient } \\
\text { irrigation to prevent or }\end{array}$ \\
\hline
\end{tabular}




\begin{tabular}{|c|c|c|c|}
\hline & & & reduce soil cracking. \\
\hline $\begin{array}{l}\text { West Indian } \\
\text { Sweet potato } \\
\text { Weevil } \\
\text { (Euscepes } \\
\text { postfasciatus) } \\
\text { (Coleoptera: } \\
\text { Curculionidae }\end{array}$ & $\begin{array}{l}\text { Adult weevils are } \\
\text { reddish brown to } \\
\text { blackish gray, and are } \\
\text { covered with short, } \\
\text { stiff, erect bristles and } \\
\text { scales. Eggs are } \\
\text { grayish yellow to } \\
\text { yellow. Larvae are } \\
\text { white. Pupae are } \\
\text { whitish and sedentary. }\end{array}$ & $\begin{array}{l}\text { Adults feed on sweet } \\
\text { potato stems and storage } \\
\text { roots, and emerge by } \\
\text { chewing exit holes. } \\
\text { Larvae feed deep in the } \\
\text { plant tissues. Internally, } \\
\text { flesh and stem tissues } \\
\text { are severely damaged. } \\
\text { Affected roots are not } \\
\text { edible by humans or } \\
\text { animals. }\end{array}$ & $\begin{array}{l}\text { Integrated pest } \\
\text { management includes } \\
\text { removal of infested sweet } \\
\text { potato vines and storage } \\
\text { roots from the field after } \\
\text { harvest, removal of } \\
\text { alternate hosts, and use of } \\
\text { uninfested planting } \\
\text { material. Biological } \\
\text { control with B. bassiana } \\
\text { and the use of early- } \\
\text { maturing varieties also } \\
\text { reduces damage. }\end{array}$ \\
\hline $\begin{array}{l}\text { Rough Sweet } \\
\text { potato Weevil } \\
\text { Blosyrus sp } \\
\text { (Coleoptera: } \\
\text { Curculionidae) } 1\end{array}$ & $\begin{array}{l}\text { Adult weevils are } \\
\text { blackish or brownish } \\
\text { and the surface of the } \\
\text { elytra is ridged. This } \\
\text { makes them look like a } \\
\text { lump of soil. Larvae } \\
\text { are whitish and C- } \\
\text { shaped. Adult weevils } \\
\text { lay eggs underneath } \\
\text { fallen leaves. The } \\
\text { larvae develop in the } \\
\text { soil and pupate there. } \\
\text { Adult weevils are } \\
\text { found on the ground } \\
\text { underneath foliage } \\
\text { during the day }\end{array}$ & $\begin{array}{l}\text { Adult weevils feed on } \\
\text { foliage, but the larvae } \\
\text { cause greater damage. } \\
\text { While feeding under the } \\
\text { soil surface, they gouge } \\
\text { shallow channels on the } \\
\text { enlarging storage roots. } \\
\text { These "grooves" reduce } \\
\text { marketability. When } \\
\text { extensively damaged, } \\
\text { the skin of the storage } \\
\text { root has to be thickly } \\
\text { peeled before eating, } \\
\text { because the flesh } \\
\text { discolours just under the } \\
\text { grooves }\end{array}$ & $\begin{array}{l}\text { Some of the cultural } \\
\text { control measures used to } \\
\text { control Cylas should be } \\
\text { effective in reducing } \\
\text { incidence of this pest, } \\
\text { especially rotation and } \\
\text { sanitation. The possibility } \\
\text { of biological control is } \\
\text { under investigation }\end{array}$ \\
\hline White Grubs & $\begin{array}{l}\text { White grubs, the larvae } \\
\text { of various species of } \\
\text { scarabid beetles, live } \\
\text { in the soil. In the larval } \\
\text { stage, they are large } \\
\text { and fleshy with } \\
\text { swollen abdomens, } \\
\text { well-developed head } \\
\text { capsules, and large } \\
\text { jaws and thoracic legs }\end{array}$ & $\begin{array}{l}\text { When they feed, white } \\
\text { grubs gouge out broad, } \\
\text { shallow depressions in } \\
\text { sweet potato roots. Most } \\
\text { species attack a wide } \\
\text { range of host plants }\end{array}$ & $\begin{array}{l}\text { Control is not usually } \\
\text { necessary. Handpicking of } \\
\text { exposed grubs during land } \\
\text { preparation and weeding is } \\
\text { useful. Light trapping can } \\
\text { be used to control white } \\
\text { grubs when they become a } \\
\text { chronic problem in a } \\
\text { localized area. }\end{array}$ \\
\hline
\end{tabular}

(Source: Ames et al., 1997) 
Table. 2 General diseases of sweet potato

\begin{tabular}{|c|c|c|}
\hline $\begin{array}{l}\text { Name of the } \\
\text { Diseases }\end{array}$ & Symptoms and Biology & Control or Solutions \\
\hline $\begin{array}{l}\text { Foot Rot } \\
\text { (Plenodomus } \\
\text { destruens) }\end{array}$ & $\begin{array}{l}\text { Brown lesions form on the stem at or below } \\
\text { the soil line. Wilting and death occur in } \\
\text { severe cases. Black pycnidia can be seen.A } \\
\text { canker extends down the stem and affects } \\
\text { the proximal end of the storage root. This } \\
\text { decay is dark brown, firm, and dry. The } \\
\text { fungus does not survive well in the soil } \\
\text { except in infected roots and stems. It is } \\
\text { spread by infected cuttings, especially those } \\
\text { from the base of the vine, and by contact } \\
\text { with } \\
\text { spores from infected roots in storage }\end{array}$ & $\begin{array}{l}\text { Diseased roots should not be } \\
\text { stored. Sanitation and the use } \\
\text { of healthy vine tips for planting } \\
\text { are the best means of control in } \\
\text { the field }\end{array}$ \\
\hline $\begin{array}{l}\text { Java Black Rot } \\
\text { (Lasiodiplodia } \\
\text { theobromae) }\end{array}$ & $\begin{array}{l}\text { This rot is firm and moist initially, but } \\
\text { storage roots soon become totally blackened } \\
\text { and mummified. Rot starts at either or both } \\
\text { ends of the storage root and is initially } \\
\text { brown, before turning black. Eruptive black } \\
\text { stromatic masses that bear pycnidia are a } \\
\text { diagnostic feature. Java black rot is spread } \\
\text { by infested soil, infected storage roots, and } \\
\text { contaminated storage boxes, baskets, or } \\
\text { tools. Infection occurs via wounds, } \\
\text { especially the cut stem end. } \\
\text { Though the pathogen can infect stems, it } \\
\text { grows very little and is seldom a problem }\end{array}$ & $\begin{array}{l}\text { Timely harvesting can reduce } \\
\text { losses. Good sanitation and } \\
\text { care in handling to reduce } \\
\text { wounding are important }\end{array}$ \\
\hline $\begin{array}{l}\text { Charcoal Rot } \\
\text { (Macrophomina } \\
\text { phaseolina) }\end{array}$ & $\begin{array}{l}\text { This disease is found only on fleshy roots } \\
\text { during storage. The fungus does not attack } \\
\text { other plant parts. Infection starts on the } \\
\text { surface of the root and progresses through } \\
\text { the vascular ring toward the pith. Three } \\
\text { distinct zones are found in a cross section of } \\
\text { an infected root: an unblemished periderm, } \\
\text { an inner zone about } 6 \mathrm{~mm} \text { wide of reddish } \\
\text { brown tissue where a crusty layer of } \\
\text { sclerotia is found, and the inner part of the } \\
\text { root with light tan tissue. Sometimes the } \\
\text { centre of the pith splits and the entire root } \\
\text { becomes mummified }\end{array}$ & $\begin{array}{l}\text { No control measures are } \\
\text { known }\end{array}$ \\
\hline $\begin{array}{l}\text { Soft Rot } \\
\text { (Rhizopus } \\
\text { stolonifer, }\end{array}$ & $\begin{array}{l}\text { Soft rotting occurs after harvest. Storage } \\
\text { roots become soft, wet, and stringy, often } \\
\text { starting at one end. A strong alcohol-like }\end{array}$ & $\begin{array}{l}\text { Washing storage roots is } \\
\text { especially conducive to rot. } \\
\text { Care in handling and proper }\end{array}$ \\
\hline
\end{tabular}




\begin{tabular}{|c|c|}
\hline sp.) & 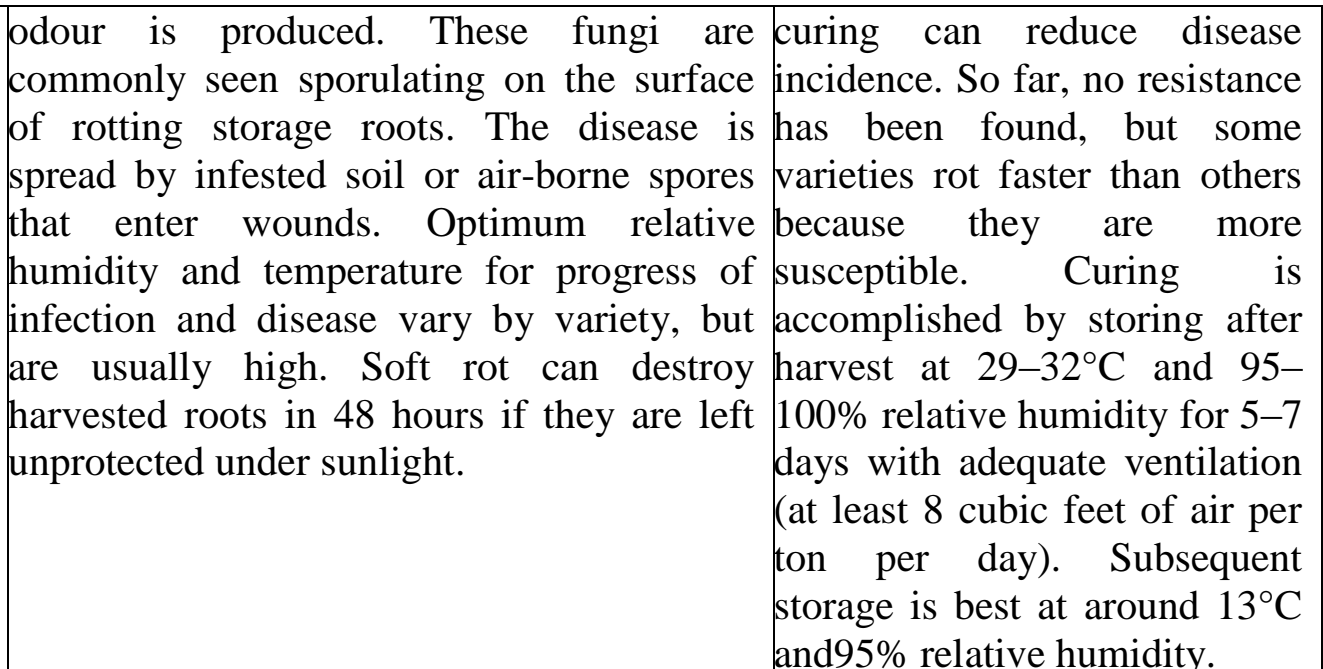 \\
\hline
\end{tabular}

(Source: Ames et al., 1997)

Table.3 Diseases caused by nematod species

\begin{tabular}{|c|c|c|}
\hline Name of the Diseases & Symptoms and Biology & Control or Solution \\
\hline $\begin{array}{l}\text { Root-Knot Nematode } \\
\text { (Meloidogyne spp.) }\end{array}$ & $\begin{array}{l}\text { Affected plants become stunted, } \\
\text { foliage turns yellow and flagging, } \\
\text { and flower production is abnormal. } \\
\text { On fibrous roots, round to spindle- } \\
\text { hhaped swellings (galls) are } \\
\text { produced together with egg masses } \\
\text { on the surface (Fig. 20). Large } \\
\text { portions of the root system can } \\
\text { become necrotic. The storage roots } \\
\text { f some varieties react with } \\
\text { longitudinal cracking (Fig. 21), } \\
\text { whereas in others, blister-like } \\
\text { protuberances emerge through the } \\
\text { epidermis }\end{array}$ & $\begin{array}{l}\text { Resistance, crop rotation } \\
\text { (such as with rice in Asia), } \\
\text { and selected nematode-free } \\
\text { planting material can help to } \\
\text { control this disease. In East } \\
\text { Africa, nematodes are rarely } \\
\text { associated with sweet potato } \\
\text { and no control measures are } \\
\text { needed. }\end{array}$ \\
\hline $\begin{array}{l}\text { Brown Ring } \\
\text { (Ditylenchus destructor) }\end{array}$ & $\begin{array}{l}\text { Fleshy roots, sometime after they } \\
\text { are stored, show symptoms as } \\
\text { depressed areas (Fig. 23). In cross } \\
\text { sections, initial infections appear as } \\
\text { necrotic isles of brown tissue } \\
\text { scattered throughout the flesh. In } \\
\text { advanced stages, the pulp becomes } \\
\text { completely blackened, slightly soft, } \\
\text { and corky (Fig. 24). These } \\
\text { nematodes affect fleshy roots only } \\
\text { during storage. No symptoms have } \\
\text { been found in the field. }\end{array}$ & $\begin{array}{l}\text { No control measures are } \\
\text { known. }\end{array}$ \\
\hline Reniform Nematode & Symptoms are not distinctive and & Rotation with non host crops \\
\hline
\end{tabular}




\begin{tabular}{|c|c|}
\hline (Rotylenchulus reniformis) & 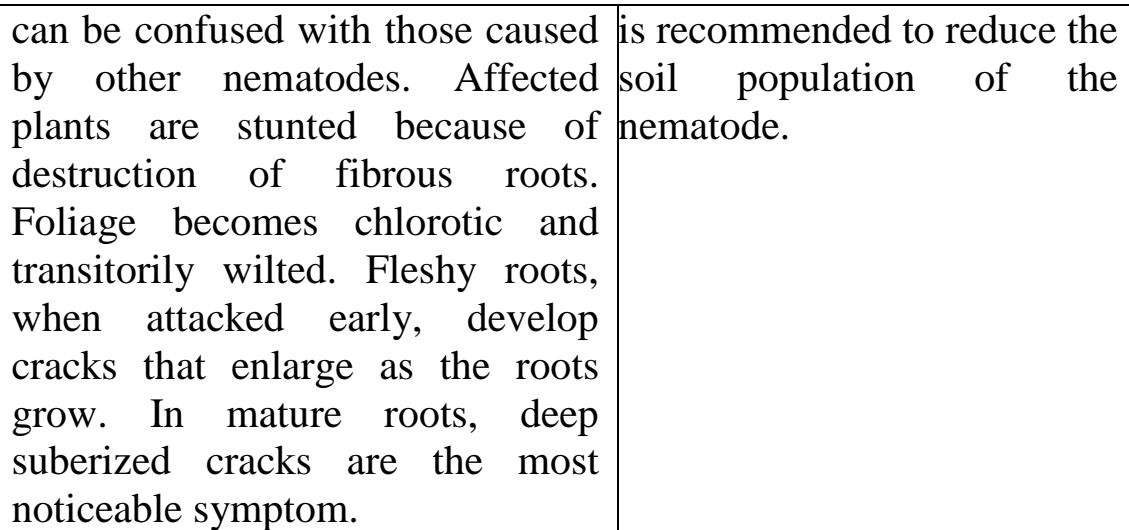 \\
\hline $\begin{array}{l}\text { Lesion Nematode } \\
\text { (Pratylenchus spp.) }\end{array}$ & 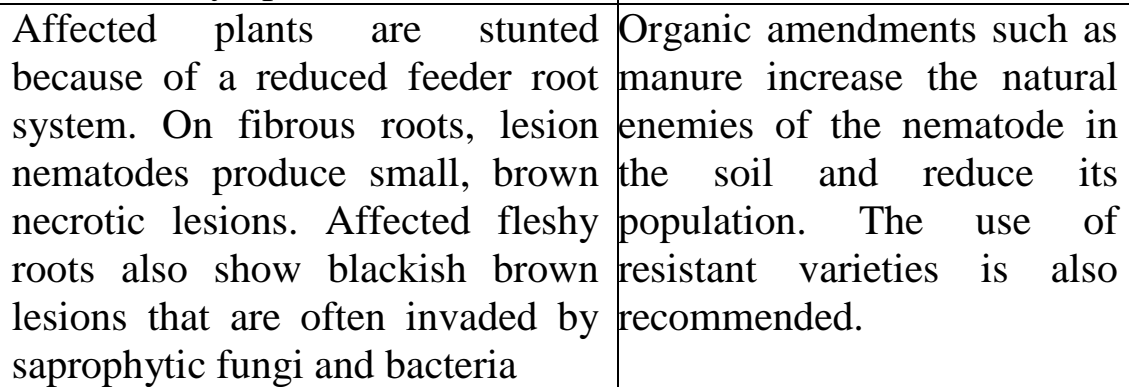 \\
\hline
\end{tabular}

(Source: Ames et al., 1997)

Table.4 Types of packaging for sweet potatoes

\begin{tabular}{|l|l|}
\hline Types & \multicolumn{1}{|c|}{ Description } \\
\hline $\begin{array}{l}\text { Corrugated } \\
\text { Fiberboard }\end{array}$ & $\begin{array}{l}\text { The most common container material. Relatively low in cost and easy to } \\
\text { print with customized labels. }\end{array}$ \\
\hline Plastic bags & $\begin{array}{l}\text { A newer, low-cost material for consumer-sized packaging. Film bags } \\
\text { are clear, allowing for easy inspection of the contents. They readily } \\
\text { accept high-quality graphics and are available in a wide range of } \\
\text { thickness, grades. }\end{array}$ \\
\hline Shrink Wrap & $\begin{array}{l}\text { One of the newer trends in packaging is shrink-wrapping of individual } \\
\text { roots, which can reduce moisture loss, reduce mechanical damage } \\
\text { during shipping, and provide a good surface for stick-on labels. Roots } \\
\text { can be shrink-wrapped in a foam tray of two or three. }\end{array}$ \\
\hline Net Bags & $\begin{array}{l}\text { Net bags bundle roots into convenient consumer sized packages, they } \\
\text { are preferred by many consumers as it limits the chance of diseases. }\end{array}$ \\
\hline Bulk Bins & $\begin{array}{l}\text { Large double or triple wall corrugated pallet bins are used as one-way } \\
\text { pallet bins to ship in bulk form to processors and retailers. }\end{array}$ \\
\hline
\end{tabular}

(Source: Mukunyadzi., 2009)

Many factors influence the market life of sweet potatoes. The cultivar, pre-harvest growing conditions, curing conditions, storage temperature, relative humidity, atmospheric oxygen/carbon dioxide composition, amount of mechanical injury during transport and distribution to market are among the most important factors influencing market life.

In conclusion, the importance of proper handling of sweet potatoes from the farmer's field to the consumer's kitchen, cannot be over emphasized. Studies show that significant 
postharvest losses occur because of improper handling and other factors. On average 20 to 25 percent loss in sweet potatoes occurs during curing and storage, 5-15 percent during shipping and retailing and 10-15 percent after sweet potatoes reach the consumer. In total, poor handling practices may result in the loss of more than half of the harvested sweet potatoes before they reach the consumer's table. To provide consumers demand with an acceptable product, attention is required in the unique postharvest technologies of sweet potatoes.

\section{Acknowledgement}

We the authors would like to express our deep gratitude towards Don-Limon $\mathrm{GmbH}$, Hamburg, Germany for giving us the opportunity to carry out our study on Literature Review of Sweet Potato.

\section{References}

Ames.T, Smit N.E.J.M, Braun A.R, O'Sullivan J.N., Skoglund L.G.(1997). Sweet potato: Major Pests, Diseases, and Nutritional Disorders:1-148. ISBN: 92-9060-187-6.

Bovell Benjamin A.C. (2007). Sweet Potato: A Review of its Past, Present, and Future Role in Human Nutrition, Advances in Food and Nutrition Research, 52:1-59.

Clark C.A and Moyer J.W.(1988).Compendium of Sweet Potato diseases. APS Press.

Grace M.H., Yousef G.G., Gustafson S.J., Truong V.D., Yencho G.C, Lila M.A.,(2013). Phytochemical changes in phenolics, anthocyanins, ascorbic acid, and carotenoids associated with sweetpotato storage and impacts on bioactive properties.Food Chemistry, 145: 717-724.
Mukunyadzi M.(2009). A Study of Sweet potato Postharvest Handling and Marketing in Chiweshe (Mazowe District) in Zimbabwe, Dissertation for award of MSc degree at Larenstein University, Wageningen, The Netherland; 56.

Onwueme I. C. (1978). The tropical tuber crops: yams, cassava, sweet potato, and cocoyams. The tropical tuber crops: yams, cassava, sweet potato, and cocoyam spp, pp 248, ISBN: 0471996076.

Padda M.S, Picha D.H. (2007). Effect of low temperature storage on phenolic composition and antioxidant activity of sweet potatoes. Postharvest Biology and Technology, 47(2):176-180.

Ray R. C., Ravi V.(2005). Post Harvest Spoilage of Sweet potato in Tropics and Control Measures, Critical Reviews in Food Science and Nutrition 45(7-8):623644.

Steed L.E, Truong V.D., Simunovic J., Sandeep K.P. Kumar P., Cartwright G.D., Swartzel K.R.(2008). Continuous Flow Microwave-Assisted Processing and Aseptic Packaging of PurpleFleshed Sweet potato Purees, Journal of Food Science, 73(9): 455-462.

Sumner P.E. (1984). Harvesting, Storage And Curing Of Sweet Potatoes, Cooperative Of Extension, The University Of Georgia College Of Agriculture, pp.2-10.

Tomlins K. I., Ndunguru G. T., Rwiza E., Westby A. (2000). Postharvest handling, transport and quality of sweet potato in Tanzania, The Journal of Horticultural Science and Biotechnology, 75 (5):586590.

Woolfe J.A. (1992). Sweet Potato an untapped food resource. ISBN: 0521402956.

\section{How to cite this article:}

Chaitali Chakraborty, Rupsa Roychowdhury, Suravi Chakraborty, Prostuti Chakravorty, Debjit Ghosh. 2017. A Review on Post-Harvest Profile of Sweet Potato. Int.J.Curr.Microbiol.App.Sci. 6(5): 1894-1903. doi: https://doi.org/10.20546/ijcmas.2017.605.210 